Tomasz Szkudlarek

https://doi.org/10.26881/ae.2019.16.03

ORCID: 0000-0001-9308-7106

Uniwersytet Gdański

tomasz.szkudlarek@ug.edu.pl

\title{
Emancypacja podmiotów, które (nie) umieją mówić
}

Joanna Rutkowiak pisze o sobie, że jest „tradycyjnym ideowcem edukacyjnym deklarującym egalitaryzm”, ale doświadczonym „w relatywnie elitarnym środowisku akademickim" (Rutkowiak 2019: 27). Pisze jednocześnie, że kształcenie polega na „wprowadzaniu ludzi na poziom intelektualny o określonym standardzie” (Rutkowiak 2019: 21). Prawdopodobnie takie rozumienie kształcenia - wraz z „elitarnie wyhodowanym" egalitaryzmem - miało wpływ na to, w jaki bezwzględny sposób traktowała swoich „peryferyjnych” studentów i jak „oburzające” było dla niej doświadczenie ich niekompetencji. A zarazem także na to, jak oburzająca dla owych studentów okazała się bezwzględność wykładowczyni. To wzajemne oburzenie stanowi punkt wyjścia dla zaistnienia opisanej w tekście sytuacji, przybierającej wyraziście pedagogiczny charakter w momencie swoistego przebudzenia, którego autorka doświadcza po słowach jednej ze studentek - dodajmy, studentki prawdopodobnie wyeliminowanej przez podobnie wymagających wykładowców (a być może przez samą autorkę). „Pani musi to wytrzymač” - mówi - rób swoje, nauczycielko, będziemy odpadać, będziemy się oburzać, ale nie przestawaj. Za tym epizodem następują kolejne. Jest ich zaledwie kilka, ale ujawniają one nieoczekiwane, trudne do wyobrażenia (a na pewno do zaplanowania) konfiguracje sytuacji edukacyjnych, niespodziewane taktyki i niezakładane efekty. Jedna studentka chce zrozumieć Feyerabenda, ponieważ treść każdego wykładu musi zreferować babci. Inny student doznaje wglądu w strukturę metodologii badań naukowych, gdy zauważa ich funkcjonalne podobieństwo do konstrukcji silnika spalinowego. Ostatecznie - jak się okazuje - w „niemożliwym” środowisku, przy „niemożliwej” konfiguracji intencji nauczycielki i oczekiwań studentów, a zapewne także dzięki bezwzględnej konsekwencji wykładowczyni ignorującej niemożliwość zawiązania relacji edukacyjnej, jakaś edukacja mogła się jednak przydarzyć. Joanna Rutkowiak interpretuje całość tego doświadczenia w perspektywie Rancière’owskiej tezy o konieczności 
ignorowania nierówności. Przekłada się to na przyjęcie kontrfaktycznego założenia równości wszystkich inteligencji (założenia wcale nie powierzchownego, jak pisze autorka - uznałbym je raczej za bezczelnie bezwzględne) i także Rancière'owskiego rozumienia emancypacji. Taka perspektywa interpretacyjna jest oczywiście produktywna. Chcę jednak tutaj rozpocząć dwutorową dyskusję. Po pierwsze, chcę spytać, w jakiej mierze przedstawione doświadczenie mieści się w optyce filozofii Jacques’a Rancière’a. Po drugie - na ile sama ta filozofia jest w stanie „ogarnąć” specyfikę współczesnych kontekstów edukacji. Opisana przez Joannę Rutkowiak sytuacja będzie tu pretekstem do zapytania o bardziej tradycyjnie pojmowaną ignorancję - też przecież obecną w tekście autorki.

Po pierwsze zatem, zmierzam do tego, że wizja Rancière’a jest tutaj nałożona na doświadczenie, które nie w całości - a przede wszystkim nie w każdej jego fazie opisanej $\mathrm{w}$ artykule - jest $\mathrm{z}$ nią spójne. Jak bowiem połączyć zacytowane na początku rozumienie kształcenia jako wprowadzania ludzi na „poziom intelektualny o określonym standardzie" (gdzie określony poziom inteligencji najwyraźniej ma się pojawić w efekcie owego wprowadzania) z założeniem równości inteligencji? Być może dlatego Joanna Rutkowiak pisze o „powierzchowności” tego Rancière’owskiego założenia. Jak wspominałem, nie wydaje mi się to trafne. Nieprawdziwość założenia równości (jego „kontrfaktyczność”) nie jest bowiem skutkiem przeoczenia czegoś istotnego; ma ono bowiem u Rancière'a charakter performatywny - nie tyle ujmuje ono to, co jest, ile umożliwia zaistnienie sytuacji edukacyjnej przerywającej dystrybucję nierówności. Trzeba je zatem rozumieć w świetle Rancière’owskiego pojmowania polityki, która w odróżnieniu od codziennej pracy „policji”, czyli „usprawniania” funkcjonowania społeczeństw w zgodzie z ustabilizowanymi regułami klasyfikacji, co oczywiście jest zarazem procesem stabilizowania owych reguł - ma zawsze charakter negatywny, jest aktywnym kwestionowaniem tego rodzaju struktur właśnie poprzez występo wanie z pozycji równości. Inaczej mówiąc, w działaniu politycznym nie ma sensu dążenie do równości, kształcenie dla niej ani domaganie sięjej: trzeba zabrać głos (dosłownie zabrać - bez proszenia o zgodę, wtrącając się, zabierając czas i przestrzeń komuś, kto nas nie zauważa); zabrać głos, którego nam się odmawia. W tym dopiero kontekście założenie równości inteligencji ukazuje swój radykalizm.

Kolejna kwestia jest szersza i wiąże się z moją wcześniejszą obserwacją (Szkudlarek 2016, 2017, 2019), że taki performatywny radykalizm nie dotyczy jedynie eksponowanego przez Rancière’a casusu Jacotota. Wskazywałem na to, że może on być warunkiem jakiejkolwiek sensownie pojmowanej edukacji. Założenia naturalnej dobroci każdego człowieka u Rousseau, powszechnej „wykształcalności” człowieka (Bildsamkeit) u Herbarta, możności resocjalizacji czy osiągnięcia sprawności w działaniach rewalidacyjnych również można potraktować jako założenia kontrfaktyczne, nieprawdziwe w punkcie wyjścia. Są one jednak warunkiem podjęcia działań, które dają szansę we r yfi ka cji takich założeń. Rancière rozumie ten termin w jego etymologicznym sensie - veri facere oznacza „czynić prawdziwym”. Nie chodzi zatem o epistemologiczne, a o performatywne rozumienie prawdziwości: 
tylko zakładając równość, będę działać jako równy i tym samym uczynię - retroaktywnie, wstecznie - to założenie prawdziwym. Ujmując to od strony nauczyciela tylko ig norując nierówność (inteligencji), stworzę przestrzeń do inteligentnego działania. Dokładnie tak ujmuje swoje doświadczenie Joanna Rutkowiak, chociaż w jej tekście pojawiło się także odwołanie do tradycyjnie pojmowanego wyrównywania, kompensowania i podobnie opisywanych działań w logice deficytu.

Nieco obok kwestii pojmowania równości versus wyrównywania inteligencji, w przedstawionym materiale empirycznym znajdujemy jeszcze jeden interesujący wątek wiążący się z filozofią emancypacji Rancière’a. Podstawowym argumentem używanym przez tego myśliciela na rzecz tezy o powszechnej równości inteligencji jest obserwacja, że w procesie edukacji nigdy nie będziemy wymagać od uczniów czy studentów niczego bardziej złożonego niż już przez nich osiągnięte - i to bez żadnej systematycznej interwencji pedagogicznej - opanowanie rodzimego języka. Skoro samodzielne przyswojenie sobie tak złożonego systemu było możliwe, skoro jednostki są podmiotami mówiącymi, to mają już wszystko, co niezbędne, aby uznać je za podmioty inteligentne i - zwłaszcza w warunkach państwa demokratycznego - wolne. To bardzo uogólniona argumentacja i szczegółowe przypadki nie mają na nią większego wpływu. Jednak w wypowiedzi jednego ze studentów Rutkowiak znajdujemy interesujące w tym kontekście stwierdzenie sformułowane przy okazji dyskusji na temat ewaluacji pisemnych prac egzaminacyjnych:

Wydawało się nam, że na egzaminie trzeba coś napisać i egzaminator powinien docenić ten wkład, nawet jeśli odpowiedź nie jest dobra, bo coś się napisało. Dopiero na poprawkowym ogarnialiśmy, że jest inny związek między pytaniami a odpowiedziami i w ogóle w rozmowach ludzi (Rutkowiak 2019: 21).

Co to znaczy - w szczególności w odniesieniu do Rancière’owskiej figury „podmiotu mówiącego”? O jakim władaniu językiem jest tu mowa - i jak ma się ono do relacji pedagogicznej? Chcę wykorzystać ten casus jako pretekst do zastanowienia się nad argumentacją Rancière'a. Ale najpierw wzmocnijmy to pytanie cytatem z wypowiedzi młodego człowieka - bynajmniej nie pochodzącego ze środowiska peryferyjnego - absolwenta elitarnego liceum z dyplomem międzynarodowej matury, syna lekarzy, biegle mówiącego kilkoma językami. W wywiadzie udzielonym Katarzynie Świerczyńskiej - dotyczącym specyfiki kulturowej pokolenia Z, od dzieciństwa żyjącego online - znajdujemy taki fragment:

- Porozmawiajmy o komunikacji. Jak z wami rozmawiać?

- To trudne. Pokolenie Z ma z tym duży problem. Często mamy trzystu znajomych w sieci zamiast trzech bliskich w rzeczywistości.

- Ty chyba nie masz z tym problemu?

- Nieprawda. Ciągle się tego uczę. Umówiliśmy się na spotkanie, bo poprosiłaś o nie. Potrafię sam wygłosić prelekcję, choć początki były trudne, ale podnieść rękę i zadać pytanie? To już nie bardzo. Nie umiem podejść do obcej osoby i jej zaczepić, zagadać. Small talking? To jest dla nas abstrakcja, coś strasznego. O tym, czy chcesz umówić się z dziewczyną, decydujesz, przesuwając jej zdjęcie w prawo lub lewo (Świerczyńska 2019). 
Kim są te dwa „mówiące podmioty”? Czy reprezentują one jakieś wspólne i ogólniejsze zjawisko? Każda $\mathrm{z}$ tych wypowiedzi może być włączona w obręb kwestii identyfikowanych w badaniach społecznych. $Z$ jednej strony znajdujemy tu ślad zrytualizowanego używania języka, prawdopodobnie skupionego wokół funkcji fatycznej (komunikacja skoncentrowana na podtrzymywaniu samego procesu komunikacji) i jednocześnie pojmowanego jako fizyczna praca, jako komunikacja podlegająca logice ekwiwalentnej wymiany: ja coś mówię - ty coś mówisz. W przypadku komunikacji za pomocą pisma dołącza się do tego wysiłek pisania zasługujący na uznanie i wypłatę w postaci oceny: „coś się napisało” - zatem inni powinni „docenić ten wkład”. W takich wymianach nie chodzi o treść przekazu. To „small talk”, o którym mowa w drugim z przytaczanych tu przypadków. Student Joanny Rutkowiak zwraca uwagę na aspekt języka (a pisma w szczególności) bardzo chętnie pomijany w refleksji pedagogicznej, a jeszcze skwapliwiej w klasycznie uprawianej humanistyce. To ciało pisze, piśmienność i alfabetyzacja wymaga fizycznego mozołu, wręcz „przerobienia” ciała w sposób umożliwiający długotrwałe unieruchomienie, podtrzymywanie nieustannie słabnącej uwagi i nauczenie się niezauważalnych dla otoczenia sposobów rozładowywania mięśniowych napięć (przeciąganie się, wiercenie się, napinanie mięśni nóg pod stołem itp.), przy zachowaniu pozorów skupionego unieruchomienia; nauczenie się precyzji mikroruchów dłoni i niewywołującej bólu pozycji ramion, bioder i nadgarstka itd. Tego rodzaju fizyczne wymiary pisma przywołuje Marta Rakoczy (2018) w swoich studiach nad piśmiennością. Jednocześnie pismo - a przede wszystkim kompozycja ciał „piszących” $i$ „niepiszących” (ręka humanisty versus ręka drwala) jest znakiem politycznej hierarchii i społecznej przynależności, swojskości albo obcości. W świetnej pracy dotyczącej funkcjonowania szkoły w Amazonii Tarzycjusz Buliński (2018) analizuje praktyki pisma, które są kierowane nie tyle na używanie go w celach komunikacji, ile na kopiowanie zachowań „ludzi pisma”. Badacz obserwował na przykład mozolne kopiowanie, a raczej „przerysowywanie” tekstów z tablicy i podręcznika do szkolnych zeszytów, które nigdy potem nie były przeglądane i lądowały w błocie. Nie chodziło w tym procesie o żaden „zapis”, o coś, co miałoby być potem czytane treść pisma nie miała tu znaczenia. Na jednej z obserwowanych przez Bulińskiego lekcji nauczyciel przepisywał na tablicy fragmenty wstępu z podręcznika wiedzy o społeczeństwie. Dotyczyły one różnic między jego pierwszym i drugim wydaniem, które uczniowie następnie przepisywali do zeszytów... i były to jedyne fragmenty podręcznika „przerobione” (z druku na pismo odręczne) w ramach przedmiotu. $\mathrm{W}$ interpretacji Bulińskiego taka praktyka pisania staje się zrozumiała jedynie w perspektywie specyfiki relacji , ludzi puszczy” $\mathrm{z}$, ludźmi miasta”. Tak jak w czasie polowania myśliwy musi się zachowywać jak tropione zwierzę, tak i w toku transakcji handlowych z „miastem” człowiek puszczy musi ukryć się w jego społecznym pejzażu jako nieodróżnialny element. Musi zatem opanować kody cielesności miejskiej kultury, w których piśmienność jest elementem niezbywalnym. W takim kontekście mówienie może rzeczywiście skupiać się na funkcji fatycznej (mówimy, 
aby mówić dalej, aby w ten sposób zaznaczać współobecność - Martin Heidegger [2004] nazwałby to "gadaniną", czymś przeciwnym mowie w rejestrze autentyczności), a pisanie staje się elementem podobnie usytuowanego rytuału zaznaczania współobecności: coś się napisało i oczekuje się stosownej na to reakcji; reakcji uznania obecności.

Co ciekawe, dobrze wykształcony człowiek pokolenia Z (zob. fragment wywiadu Katarzyny Świerczyńskiej) właśnie z tym elementem kulturowej komunikacji zdaje się mieć problem największy. „Small talking? To dla nas abstrakcja, coś strasznego”. Społeczne relacje z fizycznymi ciałami ludzi to relacje z obcymi, które trzeba "zakodować" w sposób umożliwiający nawiązywanie transakcji (zakupów albo prezentacji w środowisku szkoły - o obu tych obszarach mowa jest w wywiadzie) i to kodowanie obejmuje szereg niewerbalnych, wizualnych strategii komunikacji: staranny ubiór (markowe buty i odzież, rozmówca żali się, że w szkole uczy się detali, które natychmiast może znaleźć $\mathrm{w}$ telefonie, a nie potrafi wyprasować koszuli) i nieustanne testowanie wizerunku jako płaszczyzny nawiązywania więzi (randka na Tinderze zawiązywana przez selekcję twarzy potencjalnych partnerek albo - również wspominane w wywiadzie - „wrzucanie na Instagram” własnych zdjęć z nerwowym oczekiwaniem na liczbę lajków). Funkcja fatyczna - nawiązywanie i podtrzymywanie więzi - przeniosła się do świata wirtualnego. Komunikacja w świecie realnym najłatwiej realizuje się zaś w starannie sformalizowanych ramach behawioralnych (przedstawienie uprzednio przygotowanej prezentacji - w markowych butach i wyprasowanej koszuli), które mogą przykryć lęk przed kontaktem $\mathrm{z}$ realnością drugiego człowieka i przed ekspozycją nieobudowanego przygotowanym wizerunkiem „ja”. To komunikacja naznaczona dramatycznym lękiem: „Potrafię sam wygłosić prelekcję [...] ale podnieść rękę i zadać pytanie? To już nie bardzo”. Jednocześnie cały ten konglomerat przemieszczeń wywołuje (również wspomniany w wywiadzie) potężny głód akceptacji. Potrafię sobie wyobrazić, że dzieci pokolenia $\mathrm{Z}$ staną się bardzo łatwym łupem charyzmatycznych manipulatorów. Wystarczy okazać im akceptację, zaproponować silne przeżycie realności fizycznego doświadczenia w ściśle sformalizowanej ramie, która pozwoli na zaznanie cielesnej bliskości wolnej od ryzyka ekspozycji „nieubranego ja”. Czy można się dziwić popularności klas mundurowych, organizacji paramilitarnych i „armii Macierewicza”?

Ta pobieżna i oczywiście ryzykowna interpretacja zmierza do zarysowania pewnej wątpliwości dotyczącej Rancière’owskiej wizji „podmiotu mówiącego” jako podmiotu indywidualnej emancypacji i - co dla Rancière’a bardzo ważne - demokratycznej polityki. O ile argument, że skoro dziecko opanowało zdolność mówienia, to jest w stanie samodzielnie opanować cokolwiek, zdaje się dziś łatwy do utrzymania szczególnie w świetle współczesnych technologii - to już wiązanie tej argumentacji z emancypacją, a podmiotu mówiącego z polityką, może łatwo wylądować na mieliźnie. Nie tylko dlatego, że „umundurowanie”, niemal militaryzacja pragnienia podmiotowości to najodleglejsze antypody marzenia demokratycznego, ale także dlatego, że ruchy bliskie ideałom demokracji - jak niedawny ruch oburzonych, 
a dziś na przykład strajk klimatyczny - mogą mieć w kontekście obecnych polityk mowy i pisma walor raczej terapeutyczny niż polityczny: wyczerpią się w momentalności wydarzenia fizycznej, cielesnej bliskości niewymagającej ryzyka ekspozycji siebie - ryzyka podniesienia ręki i zadania pytania.

Wracając do edukacji - tym bardziej znaczące stają opisane przez Joannę Rutkowiak przypadki (w podwójnym sensie tego słowa: zdarzenia incydentalne i niezaplanowane). Edukacja ewidentnie ma w dzisiejszym świecie mnóstwo do zrobienia i nie chodzi chyba o naukę prasowania koszul (to na pewno można znaleźć w sieci). Pogardzana przez Heideggera "gadanina” ma fundamentalne znaczenie w tworzeniu zbiorowości (perspektywa jakoś tajemniczo, szczególnie w kontekście faszystowskiego „epizodu” w biografii tego autora, w jego myśli nieobecna); „się mówi" razem, banał (w sensie oddawanym przez angielskie commonplace) to nie tylko topos koinos antycznej retoryki; to dosłownie budulec miejsc wspólnych ludzkich przestrzeni. Warto jednak próbować przywrócić komunikacji sens wykraczający poza potwierdzanie bycia razem, sens poznawczy wykraczający poza warstwę informującą, że „tu jestem, taki sam jak wy”, sens analityczny i krytyczny. Zadbać zatem o odpowiedzialność za słowa - a ta wymaga świadomości tego, że także (a może zwłaszcza) powtarzany rytualnie banał ma charakter performatywny, że wytwarza określo ny kształt wspólnej przestrzeni, z właściwymi jej wykluczeniami i drogami przyzwolenia na przemoc wobec innych. Chodzi zatem nie tylko o bycie razem w przestrzeni wirtualnej lub fizycznej, ze wszystkimi wynikającymi z tego napięciami, wyzwaniami i trudnościami - ale też o jakość tego bycia i o to, kto i dlaczego zostanie z niego wykluczony. Znamienny jest tutaj kolejny casus studentki uczelni medycznej (zatem osoby zdolnej do myślenia i mówienia „w kodzie rozwiniętym”), która zamieściła w mediach społecznościowych pełen wulgaryzmów wpis na temat „zajmującej jej miejsce” w pociągu Ukrainki. Po wszczęciu postępowania dyscyplinarnego w uczelni i wobec perspektywy dochodzenia prokuratorskiego studentka napisała: „Przepraszam, nie myślałam, po prostu jestem głupia” (Czerniszewska 2019). Ta ostatnia konstatacja zapewne odnosi się do zauważonej w poprzednio przytaczanym wywiadzie samotności i nieumiejętności radzenia sobie z realnymi spotkaniami; do faktycznego używania mowy w intencji współudziału we wspólnocie - w jaki ejkolwiek wspólnocie, która zechce nas zaakceptować. Nacjonalizm i ksenofobia, tak wyraziście wyeksponowane we wpisie przyszłej lekarki, mogą być częścią tej układanki: pragnieniem redukcji złożoności świata, którego i bez imigrantów „nie ogarniamy”, w którym musimy się zasłonić maską wyprasowanej koszuli i przygotować do prezentacji, w którym zakładamy, że samo mówienie i pisanie - czegokolwiek - zasługuje na uznanie, bo „coś się napisało”. Dramatycznie tu brakuje połączeń między swobodnie - chciałoby się powiedzieć bezkarnie, bez sankcji w postaci negatywnych reakcji otoczenia - tworzonymi wspólnotami lajków i realnymi przestrzeniami świata, w których ludzie są różni, mają fizyczne ciała, które mogą być „do żywego” dotknięte. Pora na lekcje odpowiedzialności za słowa; na budowanie połączeń. Nie da się tego zainicjować bez nauczania, 
bez skonfrontowania fizycznie osamotnionych jednostek - dopieszczających się poczuciem akceptacji w starannie odizolowanych bąblach społecznościowych mediów - z innymi lud źmi, z kimś spoza sfery lajków i zrytualizowanych form współobecności. Dobitnie zwraca na to uwagę Gert Biesta (2017). Bez wyjścia poza uczenie się, poza konstruktywistyczne immanencje, poza „siebie”, Rancière’owska emancypacja podmiotów mówiących nie wykroczy poza narcystyczne uwalnianie się od lęku przed innymi. Polityka, a zwłaszcza demokracja, do niczego w takim świecie nie jest potrzebna. Dlatego może być tak łatwo przejęta przez demagogów wirtualnej rzeczywistości: niezauważalnie, bez oporu, z obojętnością - bo przecież „naszych" wirtualnych miejsc polityka w żaden sposób nie dotyczy, prawda?

Warto zatem przeczytać raport „z peryferii” przedstawiony przez Joannę Rutkowiak nie tylko z perspektywy Rancière'a rozumienia emancypacji, ale i przez pryzmat ponownych odkryć nauczania. Odkryć będących wyrazem sprzeciwu Gerta Biesty wobec dominujących dziś konstruktywistycznych wizji uczenia się. Nie mam wątpliwości, że nauczycielskie doświadczenie Rutkowiak świetnie ilustruje perspektywę badacza. Nawiasem mówiąc, Biesta również chętnie korzysta $\mathrm{z}$ idei Rancière’a.

\section{Literatura}

Biesta G.J.J., 2017, The Rediscovery of Teaching, London: Routledge.

Buliński T., 2018, Szkoła $w$ amazońskiej puszczy: formy i znaczenie edukacji w społecznościach tubylczych na przykładzie Indian E’ñepá $z$ Wenezueli, Gdańsk: Wydawnictwo Uniwersytetu Gdańskiego.

Czerniszewska D., 2019, Olsztyn: Studentka medycyny wyzywała Ukrainkę. Sprawa trafita do prokuratury, WP Kobieta, https://kobieta.wp.pl/olsztyn-studentka-medycyny-wyzywala-ukrainke-sprawa-trafila-do-prokuratury-6449568091355265a [dostęp: 10.12.2019].

Heidegger M., 2004, Bycie i czas, tłum. B. Baran, Warszawa: PWN.

Rakoczy M., 2018, Polityki pisma. Szkice plenerowe z pajdocentrycznej nowoczesności, Warszawa: Oficyna Naukowa.

Rutkowiak J., 2019, Rancière’owskie interpretacje emancypacyjne: doświadczanie pracy akademickiej w uczelniach niepublicznych na ziemi warmińsko-mazurskiej, „Ars Educandi” nr 16.

Szkudlarek T., 2016, On the Politics of Educational Theory: Rhetoric, Theoretical Ambiguity, and the Construction of Society, London-New York: Routledge.

Szkudlarek T., 2017, Teoria jako ontologiczna retoryka: Rousseau i krystalizacja dyskursu pedagogicznego, „Kultura-Społeczeństwo-Edukacja” nr 2.

Szkudlarek T., 2019, Postulational Rhetoric and Presumptive Tautologies: The Genre of the Pedagogical, Negativity, and the Political, „Studies in Philosophy and Education” vol. 38, iss. 4.

Świerczyńska K., 2019, „Jesteśmy skrzywdzonym pokoleniem. Królikami doświadczalnymi”, Magazyn TVN24, https://www.tvn24.pl/magazyn-tvn24/jestesmy-skrzywdzonym-pokoleniem-krolikami-doswiadczalnymi,246,4263 [dostęp: 10.12.2019]. 


\section{Streszczenie}

W swojej odpowiedzi na artykuł Joanny Rutkowiak autor wskazuje na różnice pomiędzy opisywanymi doświadczeniami nauczycielki w prowincjonalnej szkole wyższej a niektórymi elementami koncepcji Rancière'a. Prowadzi go to do krytyki Rancière'a pojmowania emancypacji, które pozostaje problematyczne wobec specyfiki generacji Z oraz narastających tęsknot za autorytaryzmem.

\section{Słowa kluczowe}

Rutkowiak, Rancière, pokolenie Z, emancypacja

\section{Summary \\ Emancipation of subjects that can(not) speak}

In his response to the article by Joanna Rutkowiak, the author explores the differences between her testimony as a teacher in a provincial university and Rancière's philosophy. This leads him to a critique of Rancière's idea of emancipation - which is seen as problematic in relation to generation $\mathrm{Z}$ specificity and an increasingly significant tendency of a longing for authoritarianism.

\section{Keywords}

Rutkowiak, Rancière, generation Z, emancipation 